\title{
RETRACTION
}

\section{Retraction: Reduced semen quality in chronic prostatitis patients that induce the release of apoptotic protein $\mathrm{Omi} / \mathrm{HtrA2}$ from spermatozoa}

XY Hu, YM Xu, Y Qiao, DL Wu, YL Sa, Q Fu, JJ Yu, XR Zhang, J Zhang, BJ Gu, R Chen and H Xie

Prostate Cancer and Prostatic Diseases (2007) 10, 398; doi:10.1038/sj.pcan.4501016

Prostate Cancer Prostatic Disease 2006; 10: 104-108. doi:10.1038/sj.pcan.4500919

The editors and the publisher retract this paper (Hu et al. http://www.nature.com/pcan/journal/v10/n1/full/ 4500919a.html) due to the appearance of severe scientific misconduct. All 12 authors were notified and informed of the retraction. Only the lead author responded and denied any misconduct. 